\title{
OPPORTUNITIES FOR CONSUMER PARTICIPATION IN POST-PURCHASE PHASE IN SERVICE VALUE CREATION
}

\author{
WiesŁaWA KuŹNiAR, ${ }^{1}$ TOMASZ SURMACZ, ${ }^{2}$ MAŁGORZATA KRZESZOWSKA ${ }^{3}$
}

Rzeszów University, POLAND

${ }^{1}$ e-mail: wkuzniar@ur.edu.pl

2 e-mail: tomasz.surmacz@gmail.com

${ }^{3}$ e-mail: m.krzeszowska@interia.pl

RECEIVED
ACCEPTED
JEL
CLASSIFICATION

KEYWORDS

ABSTRACT
8 August 2017

15 December 2017

M31, D12, L86

prosumer, services, value co-creation

Participation of clients in the creation of value for contemporary organizations refers both to companies offering material products as well as non-material ones. Services, due to some specific characteristics, and the indivisibility of providing service with consumption process, provide convenient opportunities for a client to participate in the rendering process as well as in the pre-purchase and after the completion of a service stages. Customer engagement in value creation can take many forms, both through direct contact and use of the Internet.

The aim of the article is to present the possibility of co-participation of clients in value creation of service products, with emphasis on their Internet activity. In the article, based on theoretical reflections, were presented the results of a survey conducted in 2017 among 256 young consumers. Studies have shown that respondents' prosumer activity on the Internet takes place mostly after the transaction, mostly as recommending specific service providers, and less likely sharing negative feedback. In general, the respondents rated their involvement as moderate, slightly higher in this respect were men, among whom however one in three, has assigned himself the lowest rating in this regard.

\section{Introduction}

Standard services' characteristics such as intangibility, inseparability, heterogeneity, and perishability (Gilmore, 2006, pp. 17-18) make the customer in a service company more than just a consumer/purchaser, as he becomes a co-creator of a service process. Particularly important role in this respect is played by the intangibility of services and their inseparability, which means simultaneity of service provision and consumption. S.L. Vargo, 
R.F. Lusch suggest that mutual interaction requires first and foremost building symmetric access to information, cultivating dialogue, building value-creating networks, learning by exchanging, and adopting a relational perspective (Vargo, Lusch, 2004, p. 7). As A. Hamrol states, the interaction between a service provider and a customer "cannot be reproduced in series as in production processes" (Hamrol, 2007, p. 20). The interactive nature of a service implies the involvement of a recipient, who "becomes a part of a service". Thus, it can be stated after W. Trzebiński that quality of a service and the level of satisfaction with its implementation is largely dependent on a customer himself, while the source of the difference in perception of the quality of a given service among customers is the customer's demand for the service (Trzebinski, 2006, p. 27).

It should be stressed that customers are primarily involved in contributing their value in the process of providing services. K. Rogoziński points out that a routine service order does not exclude an authentic dialogue, without which it is impossible to establish any lasting relationship between the service provider and the recipient. The cited author emphasizes the fact that the term "recipient" does not mean a reduction of client's role to passive reception. A client not only specifies his expectations for the service but also actively contributes to the service by actively participating (Rogoziński, 2000, p. 17). Consumers can also support the process of service creation at the pre-purchase phase (eg, refinement ideas, pre-testing concepts) and in the post-purchase phase (eg recommending service to other customers).

The purpose of the paper is to present the possibility of co-participation of clients in the creation of services value. Due to the young age of respondents showing the typical characteristics of digital consumers, the empirical part is focused on the Internet's pro-consumer activity, mainly related to activities in the post-purchase phase.

\section{Co-creation concept in the light of DART model}

Among the numerous authors analyzing the issue of customer value co-creation, a large contribution should be attributed to publications of C.K. Prahalad and V. Ramaswamy. In their view interactions between an enterprise and a customer in the process of co-creating services require respecting four key assumptions: dialogue, access, risk assessment, and transparency - so called DART Model (Prahalad, Ramaswamy, 2004a, pp. 23-31).

Dialogue means interaction, deep commitment and willingness to act. It includes not only exchanging or sharing knowledge, but also a whole new quality of mutual interactions (interactivity, deep commitment, listening ability, empathic understanding of consumer experience). The dialog allows users to turn their value proposition into a value-added process for the organization. This feature in the practice of service companies is implemented not only during purchase phase but also in the pre-and post-purchase phases. In practice, it requires the creation of a forum where a dialogue can take place, often involving building thematic communities around specific brands or service providers.

Access - presupposes the opportunity to take advantage of certain elements of the offer, the desired experiences without having to take possession of them. So not only at the last stage of the buying process (sale and transfer of property rights) but also at the design and product development stage, customers should be able to "experience value ". In the case of services, mainly due to their intangibility and perishability, an experience of value before purchase may be difficult, especially in relation to the so-called "pure" services.

Transparency - refers primarily to information access by customers who are involved in product development and are increasingly aware of the information they need. Transparency of information makes it easier to build 
trust between customers and manufacturers (asymmetry disappears). It should be emphasized that in relation to services, informal information from other recipients is a significant source of information for formal sources.

Risk Assessment - In recent years, debates on risk and compromising between hazards and benefits of buying specific, questionable side effects of products and services (such as hormone therapy) have intensified. The multidirectional discussion of potential risks makes consumers using their experience and knowledge capable to counteract the negative phenomena, thus taking over some of the responsibilities associated with the purchase of problematic products (Prahalad, Ramaswamy, 2004b, p. 8).

Combining elements of dialogue, transparency, risk assessment and access makes it possible for companies to take better decisions, more effectively engage clients as co-workers, or build a new quality of relationships based on dialogue and trust between equal partners (Dziewanowska, 2013, p. 46).

The application of the concept of value co-creation obliges service providers to work with clients to define problems related to the preparation of a service offering, primarily through direct contacts and social networking sites, and to identify ways to resolve them. It is essential to ensure diversity of activities, considering the increasingly individualized needs of modern consumers.

\section{Consumer of the 21st century as a co-creator of products and services value}

The consumer of the 21 st century is more and more educated and demanding towards products and services offered to him. His active approach and commitment is the result of the transition from passivity to action, from anonymity to the desire for subjective treatment, from seeking material benefits to seeking emotion, experience or contact with nature. Thanks to the rapid development of new technologies and the spread of Internet access (in Poland by the end of 2016 already $80 \%$ of households had access to the Internet - Raport strategiczny..., 2017, p. 10), the consumer of the 21 st century not only has wide access to up-to-date information but also can edit and transfer it. This activity is especially noticeable among young people, most often using the Internet (E-commerce..., 2017), who as digital consumers systematically make purchases in e-shops, using a variety of mobile applications.

In the light of the growing knowledge and activity of today's consumers, it is becoming increasingly important for companies to engage the customer in the process of contributing to the organization's value. An active, engaged client is referred to as a prosumer. This concept gained popularity in the 1980's with A. Toffler's works, who defined the prosumer as a consumer involved in the product co-creation process, to meet his or her best needs (Toffler, 1980).

The problem of dual role played by consumers is more and more often being taken up in a domestic and foreign literature of the subject. Among the proposed definitions, one can observe the lack of clarity, some authors narrow prosumption activities only to participation in product development, omitting other possibilities of influence (prosumer as a person co-creating goods and services by choice). Meanwhile, the consumer of the 21st century has an increasing role to play in creating a product and organization image, inter alia by participating in marketing communication process, especially with the use of a hypermedia computer environment. Increasing consumer activity is largely connected with the development of modern forms of communication (social networks, collaboration platforms), which allows creating a new quality of relationships with customers. Community building is related to the concept of tribalism and assumes that consumers spontaneously connect with specific brands and products, and exchange information as well as opinions, which is the first step in adopting prosumer attitudes. 
The widespread use of prosumer activity in the definition of a prosumer was emphasized among others by A.I. Baruk. According to the author, a prosumer is a buyer co-participating with a seller or/and other buyers in the process of marketing creation, whose activity contributes to generation of tangible effects (eg. products) and/ or intangible ones (eg. image, brand) beneficial to all participants of a created by this cooperation relationship system in the form of a community of marketing partners linked by strong, positive emotions (Baruk, 2017, p. 87). In reference to the complex nature of the prosumer behaviour, the author exposes, in particular the innovative, relational, image and ethnocentric dimensions of prosumer behaviours (Baruk, 2017, pp. 88-117).

In the light of the presented assumptions, the authors argue that the prosumer should be understood as a consumer conscious and engaged in the process of creating value of a product and organization at the prepurchase stage, during purchase or after a transaction who through active interaction with the organization, contributes to achievement of mutual benefits, not only in economic terms but also social or image ones.

\section{Method}

In the article, apart from the critical method of literature analysis related to the subject matter, the results of own research conducted in January 2017 on the $n=256$ sample were presented. Respondents were students of the Faculty of Economics at the University of Rzeszow at the age of $19-26,76 \%$ of the respondents were women. Nearly half of respondents (47.2\%) were rural residents, $39.0 \%$ came from cities up to 100 thousand, while $13.8 \%$ represented cities over 100 thousand residents. Random non-probability sampling was applied. In addition to the basic descriptive statistics measures, variance analysis was used and the NIR significance test at $\alpha=0.05$.

\section{Results}

The research was aimed at identifying the involvement of respondents in the process of creating value of selected services among the surveyed consumer groups, who mainly use the Internet to express their opinions and assessments. These are people who usually search before buying, looking for other users' opinions, ask questions on the web, describe products themselves, promote their values, and recommend buying to others.

With regard to service units, the activity of consumers in the post-purchase phase primarily comes down to evaluation of transaction satisfaction as well as recommending the product/company to other potential customers (Table 1).

Table 1. Activity of respondents in expressing their own opinions on selected types of services (\%)

\begin{tabular}{lcc}
\hline & Type of service & Percentage of respondents making at least one assessment: \\
\cline { 2 - 3 } & positive & negative \\
\hline Trade & 52.0 & 41.8 \\
Gastronomic & 50.4 & 43.0 \\
Education & 45.3 & 34.8 \\
Banking & 41.0 & 30.9 \\
Tourism & 40.6 & 30.5 \\
Public administration & 36.3 & 32.0 \\
Medical & 35.9 & 30.1 \\
Insurance & 33.2 & 28.1 \\
\hline
\end{tabular}

Source: own calculations based on survey data, $n=256$. 
The results of the study show that the greatest activity in terms of expressing their post-purchase feelings was noticed in relation to commercial and catering services, which at least once on their own initiative was performed by more than half of the respondents. It is worth emphasizing that positive feelings are shared more often than negative ones. It is also worth pointing out that similar situation was observed in relation to all examined services. The lowest evaluation activity was recorded for public administration, medical and insurance services, with an average of one out of every three respondents. Gender analysis of respondents showed that male respondents were more active in expressing opinions, both positive and negative (Table 2).

Table 2. Activity of respondents in expressing written opinions on selected types of services, regarding sex (\%)

\begin{tabular}{lcccc}
\hline & \multicolumn{3}{c}{ Percentage of respondents making at least one assessment } \\
\cline { 2 - 5 } & \multicolumn{3}{c}{ positive } & \multicolumn{3}{c}{ negative } \\
\cline { 2 - 5 } & women & men & women & men \\
\hline Trade & 47.1 & 67.2 & 36.4 & 56.9 \\
Gastronomic & 46.0 & 60.3 & 35.9 & 60.3 \\
Education & 40.4 & 56.9 & 28.8 & 50.0 \\
Banking & 37.4 & 48.3 & 25.3 & 44.8 \\
Tourism & 37.9 & 44.8 & 25.3 & 43.1 \\
Public administration & 31.8 & 46.6 & 26.3 & 48.3 \\
Medical & 32.3 & 46.6 & 25.3 & 44.8 \\
Insurance & 28.8 & 43.1 & 22.7 & 41.4 \\
\hline
\end{tabular}

Source: own calculations based on survey data, $n=256$.

In order to determine whether gender of respondents has a statistically significant impact on the level of post-purchase activity, the analysis of variation and NIR significance test were performed. Based on the obtained results, it can be concluded that gender has significantly influenced the consumer's commitment, as evidenced by the value of probability $p$ level of 0.00002 . Men rated their activity in opinion sharing significantly higher than women. A higher level of activity by men is found for all types of services analysed. The most noticeable is the assessment of insurance services, least banks, and catering services. It is worth pointing out that the surveyed consumers statistically significantly $(p=0.00013)$ more frequently assessed their activity in positive opinions $41.8 \%$ than negative $33.9 \%$. It is visible both for men (51.7 and $48.5 \%$ respectively) and for women ( 37.7 and $28.3 \%$, respectively). This consistency is reflected in all types of services analyzed, except for office services, where men were marginally less positive (46.6\%) than negative (48.3\%).

According to research conducted by the authors, besides expressing their opinions after the transaction, consumers also use other forms of product/company support, such as liking/ sharing in social media, as indicated by the vast majority (nearly $80 \%$ ) of the respondents. It is worth emphasizing that seven out of ten respondents have done it several times or do it often (Kuźniar, Surmacz, Szopiński, 2017).

In the final part of the survey, consumers were asked to specify on a scale of 1-5, to what extent do they feel as so-called active consumers, having at least partly impact on the structure of service products or creating the image of a company they use (Table 3). 
Tahle 3. Overall self-evaluation of respondents' participation in the process of creating value of purchased services

\begin{tabular}{|c|c|c|c|}
\hline \multirow{2}{*}{ Description } & \multirow{2}{*}{ Total } & \multicolumn{2}{|c|}{ Sex } \\
\hline & & women & men \\
\hline General assessment on $1-5$ scale & 2.47 & 2.46 & 2.48 \\
\hline \multicolumn{4}{|l|}{ Percentage of extreme assessments } \\
\hline - assessment $1(\%)$ & 23.00 & 21.20 & 29.30 \\
\hline - assessment $5(\%)$ & 2.30 & 1.52 & 5.20 \\
\hline
\end{tabular}

*1 means lack of engagement, 5 - very high engagement.

Source: own calculations based on survey data, $n=256$.

The research shows that respondents rated their involvement as moderate. Men ranked slightly higher in this regard, yet every third men gave himself the lowest score. The highest ratings, reflecting very high prosumers' activity, occurred only for a small number of respondents.

\section{Conclusions}

The process of contributing to the value of an organization refers both to companies offering tangible products and services. Knowledge, experience and customer engagement allow, among others, to define common problems, to indicate how to solve them, or to recommend to other users. In this respect, the Internet offers a wide range of possibilities in which users in many ways can express their acceptance or dissatisfaction with a specific market offer. Their activity in the network is not only to receive marketing communications, but also to edit or share opinions about products and brands with other users. They also express their engagement by making posts available in social media, participating in product knowledge contests, submitting their ideas, and disseminating consumer knowledge.

When it comes to services, providers seek to leave the recipient free to shape the structure of the service to meet the specificity of the buyer's expectations. It is increasingly important for service providers to be open to innovative solutions, especially in the field of communication, which enables active dialogue and allows them to cocreate and survive the creation of a service offering. An active role in this area is the activity of consumers after the purchase of a service, who on the Internet share their feelings and opinions, thus contributing not only to increased sales of service offerings but also to strengthening the image of the organization.

\section{References}

Baruk, A.I. (2017). Prosumpcja jako wielowymiarowe zachowanie rynkowe. Warszawa: Polskie Wydawnictwo Ekonomiczne.

Dziewanowska, K. (2013). Wykorzystanie koncepcji współtworzenia w nowym podejściu marketingowym. Handel Wewnętrzny, 3.

E-commerce w Polsce 2016 (2017). V Gemius dla e-Commerce Polska.

Gilmore, A. (2006). Usługi. Marketing i zarządzanie. Warszawa: Polskie Wydawnictwo Ekonomiczne.

Hamrol, A. (2007). Zarządzanie jakością z przykładami. Warszawa: Wydawnictwo Naukowe PWN.

Kuźniar, W., Surmacz, T. Szopiński, W. (2017). Wirtualizacja konsumpcji i jej oddziaływanie na kształtowanie postaw i zachowań prosumpcyjnych wśród młodych konsumentów. Annales Universitatis Mariae Curie-Skłodowska Sectio H Oeconiomia, 2 (52), 143-150.

Prahalad, C.K., Ramaswamy, V. (2004a). The future of competition. Co-Creating Unique Value with Costumers. Boston: Harvard Business School Press. 
Prahalad, C.K., Ramaswamy, V. (2004b). Co-creation experiences: the next practice in value creation. Journal of Interactive Marketing, 3 (18).

Raport strategiczny. Internet 2016/2017 (2017). Retrieved from: https://iab.org.pl/wp-content/uploads/2017/06/IAB_Raportstrategiczny_INTERNET_2016_2017_FIN.pdf (5.08.2017).

Rogoziński, K. (2000). Nowy marketing usług. Poznań: Wydawnictwo Akademii Ekonomicznej w Poznaniu.

Toffler, A. (1980). The third wave. New York: William Morrow \& Co.

Trzebiński, W. (2016). W jaki sposób klienci dokonują oceny usługi? Warszawa: Oficyna Wydawnicza SGH.

Vargo, S.L., Lusch, R.F. (2004). Evolving to a new dominant logic for marketing. Journal of Marketing, 68.

Cite this article aS: Kuźniar, W., Surmacz, T., Krzeszowska, M. (2018). Opportunities for consumer participation in post-purchase phase in service value creation. European Journal of Service Management, 2 (26), 137-143. DOI: 10.18276/ejsm.2018.26-17. 